\title{
Applications of Immobilized Bio-Catalyst in Metal-Organic Frameworks
}

\author{
Qi Wang ${ }^{(i)}$, Xizhen Lian, Yu Fang ${ }^{(D)}$ and Hong-Cai Zhou * (D) \\ Department of Chemistry, Texas A\&M University, P.O. Box 30012, College Station, TX 77842-3012, USA; \\ qi.wang@chem.tamu.edu (Q.W.); xizhen.lian@chem.tamu.edu (X.L.); yu.fang@chem.tamu.edu (Y.F.) \\ * Correspondence: zhou@chem.tamu.edu; Tel.: +1-979-845-4034
}

Received: 9 April 2018; Accepted: 18 April 2018; Published: 20 April 2018

\begin{abstract}
Immobilization of bio-catalysts in solid porous materials has attracted much attention in the last few decades due to its vast application potential in ex vivo catalysis. Despite the high efficiency and selectivity of enzymatic catalytic processes, enzymes may suffer from denaturation under industrial production conditions, which, in turn, diminish their catalytic performances and long-term recyclability. Metal-organic frameworks (MOFs), as a growing type of hybrid materials, have been identified as promising platforms for enzyme immobilization owing to their enormous structural and functional tunability, and extraordinary porosity. This review mainly focuses on the applications of enzyme@MOFs hybrid materials in catalysis, sensing, and detection. The improvements of catalytic activity and robustness of encapsulated enzymes over the free counterpart are discussed in detail.
\end{abstract}

Keywords: metal-organic frameworks (MOFs); enzyme immobilization; bio-catalyst; conversion; sensing

\section{Introduction}

The history of utilizing bio-catalysts in production dates back to thousands of years ago when human learned to make alcohol from sugar via fermentation with the addition of yeast or other microorganisms. With the fusion of ideas from modern protein chemistry and molecular biology, enzymes, as nature's catalysts, have been extensively applied in industrial production, such as drug and food production [1-3]. However, these applications are limited by the relatively low stability of enzymes, for example, weak thermal stability and high sensitivity to $\mathrm{pH}$ changes, which results in the lack of long-term recyclability and difficulty of separating enzymes from products [4,5]. A possible strategy to overcome these issues is heterogeneously immobilizing enzymes on solid supports, which keeps enzymes in the confined microenvironment and prevents enzymes from denaturing [6-8].

Metal-organic frameworks (MOFs) are an emerging porous materials assembled by the coordination of metal ions or clusters with organic linkers [9-11]. MOFs are highly tunable platforms in terms of structure and functionality [12,13]. Thus, MOFs have shown promising potentials in gas adsorption and separation, catalysis, photosynthesis, biomedicine, and so on [14-25]. The high surface area, large pore volume, and high stability of MOFs indicate that they are ideal for enzyme immobilization [26-30]. This review mainly focuses on the applications of immobilized enzyme@MOFs materials in biomimetic catalysis and conversion, sensing, and detection. The performance of immobilized enzymes will be compared with the free counterparts and the merits imparted from immobilization will be discussed.

\section{Applications of Enzyme@MOFs Materials in Catalysis, Sensing, and Detection}

Due to the high selectivity nature of enzymes, the applications of immobilized enzyme@MOFs materials are mainly for catalysis, sensing, and detection. Immobilized enzymes are separated by 
the pores of MOFs, which avoids their aggregation and facilitates high conversion rate. In addition, the physical confinement of the immobilized enzymes by the cavity wall of MOFs prevents the occurrence of protein denaturation.

The synthetic approaches of enzyme@MOF materials also play a key role in their practical performances, especially in the aspect of promoting substrate diffusion and prohibiting enzyme leaching. Typically, the synthetic approaches can be classified into two major categories: one-pot synthesis and post-synthetic immobilization. One-pot synthesis, also known as biomineralization or co-precipitation, encapsulates the enzymes in the material through the formation of coordination porous shell structures. The core-shell structure creates diffusion pathways for substrates contacting the encapsulated enzymes. Post-synthetic immobilizations, including the formation of covalent and non-covalent bonds between MOF and enzymes, also provides strong host-guest interactions and accessible enzyme active sites.

\subsection{Biomimetic Catalysis and Conversion}

\subsubsection{Chemical Conversion}

Park et al. reported the covalent attachment of enhanced green fluorescent protein (EGFP) and Candida-antarctica-lipase-B (CAL-B) in $1 \mathrm{D}\left(\left[\left(\mathrm{Et}_{2} \mathrm{NH}_{2}\right)\left(\operatorname{In}(\mathrm{pda})_{2}\right)\right]\right.$, pda $=1,4$-phenylenediacetate), 2D $\left(\left[\mathrm{Zn} \text { (bpydc) }\left(\mathrm{H}_{2} \mathrm{O}\right)\left(\mathrm{H}_{2} \mathrm{O}\right)\right]_{\mathrm{n}}\right.$, bpydc $=2,2^{\prime}$-bipyridine 5,5'-dicarboxylate), and 3D (IRMOF-3) MOFs [31] The carboxylate groups on the MOF surface were first activated and then reacted with the amino groups on the enzymes (Figure 1). The catalytic activity of the immobilized CAL-B was verified through transesterification of ( \pm )-1-phenylethanol. CAL-B immobilized on IRMOF-3 showed $10^{3}$-fold higher activity than that of free CAL-B, while maintaining the same enantioselectivity. The authors proposed that the confined spaces in MOFs allow substrates to access enzymes more efficiently. Moreover, after three catalytic cycles, no significant decrease of enzymatic activity was observed.

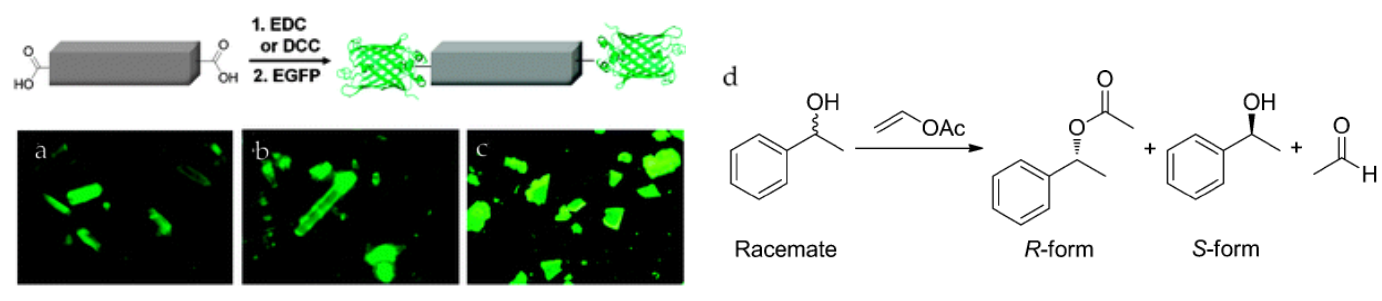

Figure 1. Schematic representation of the bioconjugation of the 1D-polymer, $\left[\left(\mathrm{Et}_{2} \mathrm{NH}_{2}\right)\left(\operatorname{In}(\mathrm{pda})_{2}\right)\right]_{\mathrm{n}}$, with EGFP. Fluorescence microscopic images of EGFP coatedMOFs. (a) 1D + EGFP; (b) 2D + EGFP; (c) 3D + EGFP. An Olympus WIB filter set $\left(\lambda_{\mathrm{em}}=460-490 \mathrm{~nm} ; \lambda_{\mathrm{em}}>515 \mathrm{~nm}\right)$ was used for recording the fluorescence [31]; and (d) the catalytic reaction of racemate and the product enantiomers. Reproduced from [31] with permission from the Royal Society of Chemistry, copyright 2011.

Ma group first reported the immobilization of MP-11 into a mesoporous MOF, Tb-mesoMOF $\left[\mathrm{Tb}_{16}(\mathrm{tatb})_{16}\right.$, tatb = triazine-1,3,5-tribenzoate], consisting of cages with diameters of $0.9,3.0$, and $4.1 \mathrm{~nm}$ (Figure 2) [32]. After the loading of MP-11, the 3.0 and $4.1 \mathrm{~nm}$ cavities disappeared, while the $0.9 \mathrm{~nm}$ pore still existed, indicating the occupation of the enzyme in large pores and the accessible small pores for substrate diffusion. The BET surface area of Tb-mesoMOF drops from $1935 \mathrm{~m}^{2} / \mathrm{g}$ to $400 \mathrm{~m}^{2} / \mathrm{g}$ after MP-11 loading of $19.1 \mu \mathrm{mol} / \mathrm{g}$. MCM-41, a mesoporous silica material with a lower surface area at $\sim 1000 \mathrm{~m}^{2} / \mathrm{g}$ and a lower loading of $3.4 \mu \mathrm{mol} / \mathrm{g}$ [33], was also applied for MP-11 encapsulation. The MP-11@Tb-mesoMOF catalyzed the oxidation of 3,5-di-tert-butyl-catechol in the presence of $\mathrm{H}_{2} \mathrm{O}_{2}$. In comparison to free MP-11 and MP-11@MCM-41, MP-11@Tb-mesoMOF showed a much higher conversion percentage, reaction rate, and better recyclability after seven cycles. Proved by the bathochromic shift of the immobilized MP-11 in Tb-mesoMOF compared to free MP-11, 
the hydrophobic interactions between the hydrophobic nanocage of Tb-mesoMOF and MP-11 were attributed to the better performance of MP-11@Tb-mesoMOF over free MP-11.

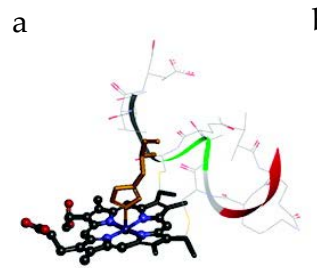

d<smiles>CC(C)(C)c1cc(O)c(O)c(C(C)(C)C)c1</smiles>

3,5-di-tert-butyl-catechol
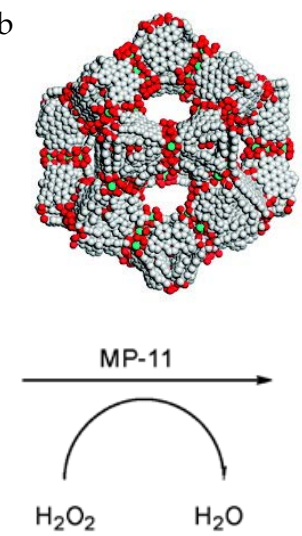
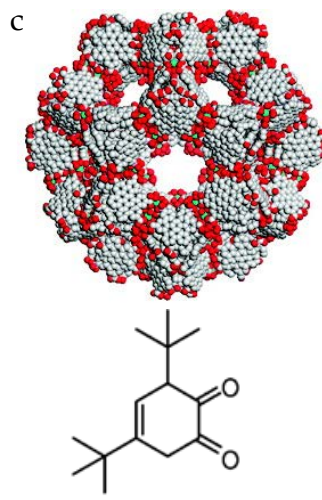

Figure 2. (a) Molecular structure of MP-11 (obtained from the solution structure of PDB 1OCD); (b) the $3.9 \mathrm{~nm}$-diameter cage; (c) the $4.7 \mathrm{~nm}$-diameter cage in Tb-mesoMOF; and (d) the reaction scheme for oxidation of 3,5-di-t-butylcatechol to $o$-quinone [32]. Reproduced from [32] with permission from American Chemical Society, copyright 2011.

Zhou and co-workers reported two mesoporous MOFs, $\mathrm{PCN}-332$ and -333, composed of $\mathrm{M}_{3} \mathrm{O}$ clusters and tritopic linkers (Figure 3) [34]. PCN-333(Al) showed good stability in a pH range of 3-9 and exhibited hierarchical cavities with sizes of $1.1 \mathrm{~nm}, 4.2 \mathrm{~nm}$, and $5.5 \mathrm{~nm}$. The mesoporous cages functioned as single-molecule traps (SMTs) to encapsulate HRP and Cyt-c, whereas MP-11 as a smaller enzyme was immobilized by multiple-enzyme encapsulation (MEE). PCN-333(Al) demonstrated record-high enzyme loading capacity and much better recyclability than porous silicate materials, for example, SBA-15. In particular, PCN-333(Al) immobilized HRP and Cyt-c exhibited stronger substrate affinity and improved catalytic performance over free enzymes owing to the separation of enzymes in the cages, which prevents the undesirable self-aggregation during the reaction.
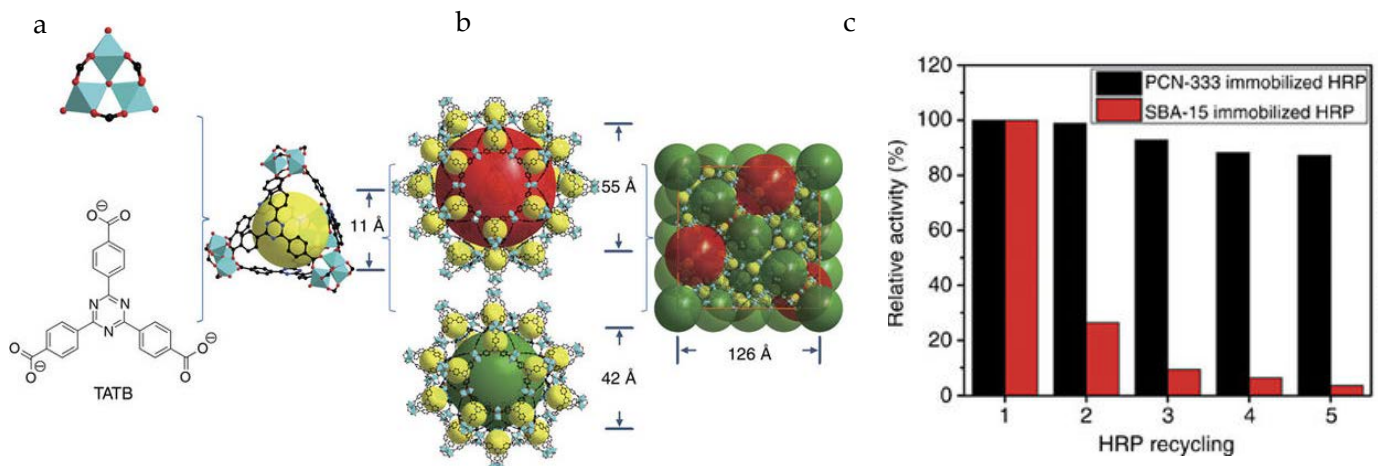

Figure 3. (a) Ligand and cluster used in PCN-333; (b) Three different cages in PCN-333; (c) Catalytic activity of immobilized enzymes in each recycle test [34]. Reproduced from [34] with permission from Springer Nature, copyright 2015.

Falcaro et al. provided a biomineralization approach to encapsulate biomacromolecules in ZIF-8 [35]. The ZIF-8 / proteins were simply prepared by soaking the protein in 2-methylimidazole aqueous solution and mixed with zinc acetate aqueous solution. The activity of ZIF-8/HRP was examined by monitoring the rate of $\mathrm{H}_{2} \mathrm{O}_{2}$ decomposition with pyrogallol as the hydrogen donor, which can be converted to a yellowish product, purpurogallin. Owing to the excellent stability of ZIF-8, the coated DNA, proteins, and enzymes exhibited much-improved chemical and thermal stability. 
For example, the immobilized HRP maintained its catalytic activity in boiling water $\left(100{ }^{\circ} \mathrm{C}\right)$ or in boiling DMF $\left(153^{\circ} \mathrm{C}\right)$.

\subsubsection{Protein Digestion and Chemical Degradation}

Trypsin is a commonly-used protease that catalyzes protein digestion and transformation into peptides for proteomics analysis and industrial production. The practical application of trypsin often suffers from the long running time (18-24 h) and self-digestion in the reaction media [36] Immobilization on MOFs is capable of preventing the self-digestion and improve their recyclability. Unlike most of the catalytic reactions for chemical conversions, the substrates of trypsin are proteins, which are typically larger than the pore size of MOFs. Thus, trypsin is normally attached to the surface of MOFs instead of encapsulated inside of the pores to allow better substrate accessibility. Bovine serum albumin (BSA) digestion is usually used as the model reaction.

Lin and Huang et al. reported a novel trypsin-FITC@MOF bioreactor that showed high protein digestion efficiency [37]. Trypsin was first modified with fluorescein isothiocyanate dye (FITC) by bioconjugation via microwave. Then, FITC was trapped in the cavity of CYCU-4 ([Al(OH)(SDC)], SDC $=4,4^{\prime}$-stilbenedicarboxylic acid) through strong $\pi-\pi$ interaction and hydrogen bonding between FITC and MOF linker. In the BSA digestion test, FITC@CYCU-4 obtained 47 matched peptides and 72\% sequence coverage confirmed by nanoLC-MS ${ }^{2}$ followed with Mascot database searching. These results were comparable to free trypsin-FITC. The same group also reported a similar dye-assisted enzyme immobilization method utilizing a small molecular dye, 4-chloro-7-nitrobenzofurazan (NBD) [38]. The dye-modified trypsin exhibited the best activities when immobilized on CYCU-4 and UiO-66, which demonstrated $69-71 \%$ conversion percentage even after five consecutive catalytic cycles. On the contrary, NBD-FITC@MIL-100 or MIL-101 only demonstrated moderate activities. This can be ascribed to the size mismatch between NBD and the cavities of MOFs (MIL-100 or MIL-101).

The same group synthesized covalent linkage trypsin-MOF composite (Figure 4) [39]. MIL-101(Cr), MIL-88B(Cr), and MIL-88B- $\mathrm{NH}_{2}(\mathrm{Cr})$ were firstly activated by $N, N^{\prime}$-dicyclohexylcarbodiimide (DCC) and then conjugated with trypsin through the formation of peptide bonds. The digestion of BSA was performed with the assistance of ultrasonication for $2 \mathrm{~min}$. Trypsin-MIL- $88 \mathrm{~B}-\mathrm{NH}_{2}(\mathrm{Cr})$ showed much higher amino acid sequence coverage percentage and more matched peptides than the other two composites. This can be ascribed to the higher substrate affinity of MIL-88B- $\mathrm{NH}_{2}$ through the hydrogen bond between the surface amino groups on MOF and the protein. The BSA digestion result of trypsin-MIL-88B- $\mathrm{NH}_{2}$ was similar to that of free trypsin, indicating that the immobilization did not compromise enzyme activity or substrate accessibility.

Hupp and Farha et al. reported the encapsulation of organophosphorus acid anhydrolase (OPAA), a nerve agent detoxifying enzyme, by using PCN-128y $\left(\left[\mathrm{Zr}_{6} \mathrm{O}_{4}(\mathrm{OH})_{8}(\mathrm{ettc})_{2}\right]\right.$, ettc $=\left(4^{\prime}, 4^{\prime \prime}, 4^{\prime \prime \prime}, 4^{\prime \prime \prime \prime}\right.$-(ethene-1,1,2,2-tetrayl)tetrakis-([1,1'-biphenyl]-4-carboxylate)) (Figure 5) [40]. $\mathrm{PCN}-128 \mathrm{y}$ is a water-stable MOF that possesses $4.4 \mathrm{~nm}$ mesoporous 1-D channels. Diisopropyl fluorophosphate (DFP), a less toxic nerve agent simulant, and Soman, an extremely toxic nerve agent, were detoxified by OPAA@PCN-128y. PCN-128y achieved 12 wt \% loading of OPAA. Both free OPAA and immobilized OPAA reached the conversion percentage of $80-90 \%$ for DFP. The immobilized OPAA demonstrated a considerably better conversion percentage than free OPAA at elevated temperature and after three days. The hierarchical structure of PCN-128y allows it to host OPAA in the large channels and has an efficient mass transfer of reactant and product in the smaller channels. 


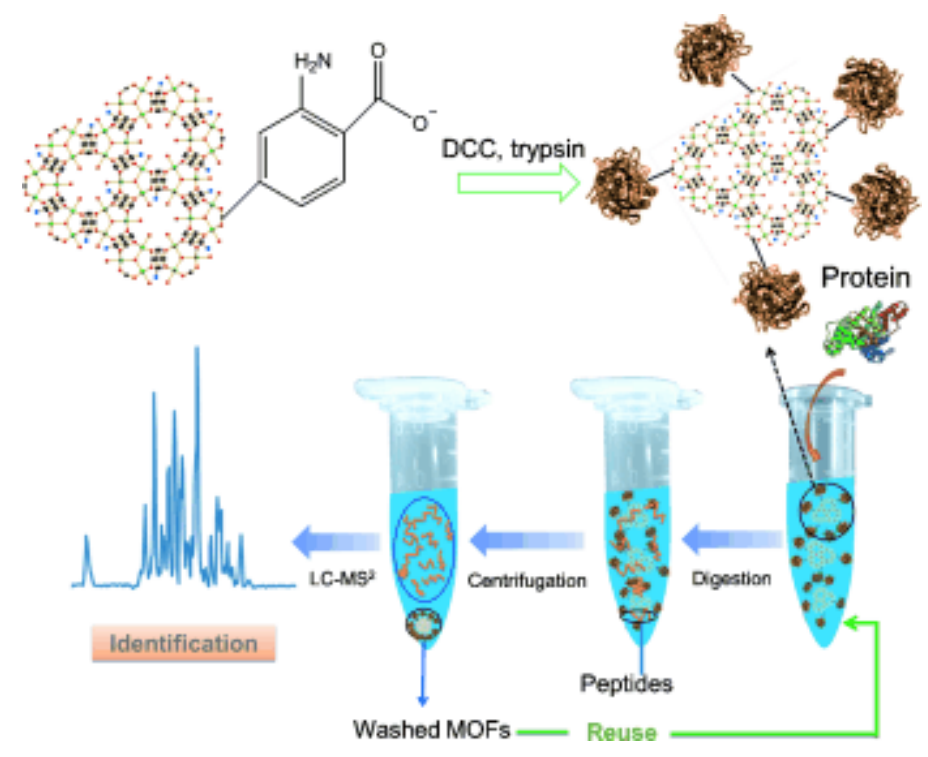

Figure 4. Schematic of trypsin immobilization on MIL-88B- $\mathrm{NH}_{2}(\mathrm{Cr})$, protein digestion through trypsin-MOF, and identification by LC-MS². Reproduced from [39] with permission from John Wiley and Sons, copyright 2012.
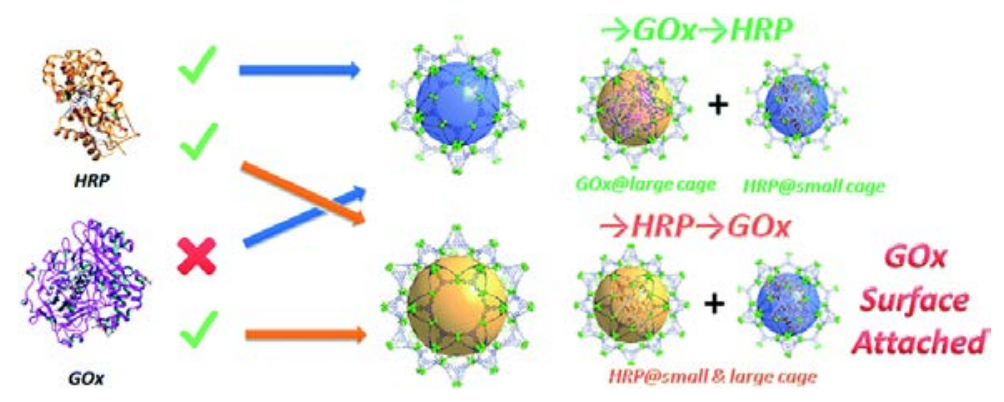

Figure 5. Schematic of the results of the stepwise encapsulation of GOx and HRP with different loading orders in PCN-888. Reproduced from [41] with permission from Royal Society of Chemistry, copyright 2016.

\subsubsection{Tandem Reaction with Multiple Enzymes}

Tandem reaction is a chemical process that comprises at least two consecutive reactions [42]. The products of the previous step become the substrates in the next step of the reaction under the same condition without the necessity of isolating the intermediates. Thus, compared with single enzyme immobilization, more delicate designs are needed to immobilize multiple enzymes in the same system to catalyze tandem reactions.

Inspired by the hierarchical structure and ligand extension strategy, PCN-888 was rationally designed as a tandem nanoreactor that possessed even larger cavities for the co-encapsulation of HRP and GOx (Figure 5) [41]. The loading order of the two enzymes (GOx first, HRP second) was essential for the preparation of the bi-enzyme nanoreactor. The reversed order would end up loading HRP in both large and intermediate pores and attaching GOx only on the MOF surface. In the bi-enzyme system, GOx catalyzed the oxidation of glucose by oxygen, yielding gluconolactone and hydrogen peroxide. The latter was the substrate in the conversion of ABTS to ABTS ${ }^{+}$catalyzed by HRP. The generation of $\mathrm{ABTS}^{+}$, as monitored by UV-VIS spectroscopy at $403 \mathrm{~nm}$, was utilized to trace the reaction. The leaching of enzymes from $\mathrm{PCN}-888$ was negligible, which could be due to the presence of the $\pi-\pi$ interaction between the enzyme and the conjugated heptazine core and terminal benzene rings on the ligands. 
A recent work by Zhou et al. reported the encapsulation of two antioxidative enzymes, SOD and CAT, in fluorescent nanoscale PCN-333 (FNPCN-333) for the removal of toxic reactive oxygen species from human cells [43]. SOD catalyzes the disproportionation of superoxide and generates hydrogen peroxide and oxygen. Hydrogen peroxide is further decomposed into water and oxygen catalyzed by CAT. The loading of SOD and CAT was conducted in a similar stepwise manner. The as-synthesized "nanofactory" was tested to be stable in the acidic environment and was enzymatically functional in endocytic organelles. Compared with free enzymes, the enzyme@MOF nanofactory demonstrated intracellular enzymatic activity for up to a week, thanks to the MOF protection against the proteolytic digestion and acidic organelle environment.

\subsection{Applications in Sensing and Detection}

Bio-catalyst immobilized sensing and detection devices, in other words, biosensors, are of great interest in the field of glucose monitoring, food analysis, cancer diagnosis, etc. Especially, glucose biosensors account for approximately $85 \%$ of the entire biosensor market owing to the great need of millions of daily diabetics test to monitor blood glucose levels [44]. GOx, GDH, and hexokinase are three of commonly-used enzymes for glucose measurements [45]. The general aim of the design of a biosensor is to allow quick and convenient testing at the point of concern or care where the sample is procured. This requires the enzymes of the biosensors to be stable and functional in an unnatural environment. Thus, MOFs are considered as promising immobilization matrices to effectively protect the enzymes against perturbations.

Mao and Yang et al. utilized a series of zeolitic imidazolate frameworks (ZIFs), including ZIF-7, $-8,-67,-68$, and -70 , as the matrices to immobilize methylene green (MG) and GDH as biosensors (Figure 6) [46]. To prepare the biosensor, a MG/ZIF composite was drop-coated on a glassy carbon electrode and then GDH was coated. Among the five ZIFs, MG/ZIF-70 composite biosensor showed the best performance with a glucose sensitivity linear range of $0.1-2 \mathrm{mM}$ and a sensitivity of $54 \mathrm{~mA}$ $\mathrm{M}^{-1} \mathrm{~cm}^{-2}$. In addition, this ZIF-based biosensor demonstrated a quick response and high selectivity for in vivo monitoring of glucose in the cerebral system.

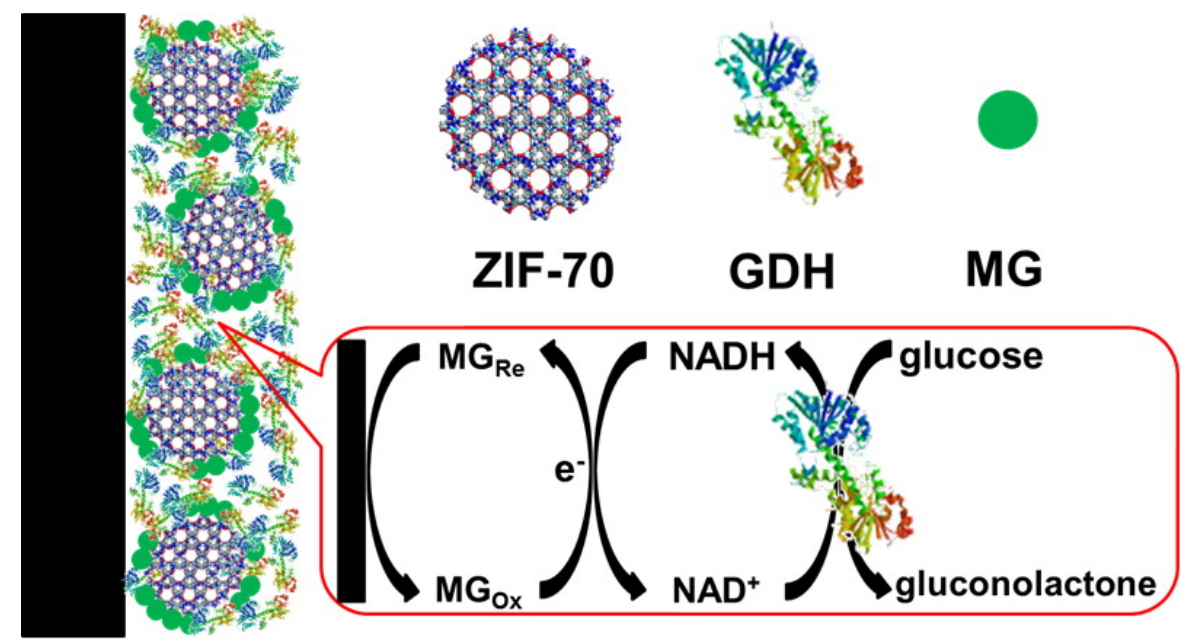

Figure 6. Schematic of the design of ZIF-70-based electrochemical biosensor. Reproduced from [46] with permission from American Chemical Society, copyright 2013.

Mass transfer and electron transfer are two fundamental factors for an effective biosensor. Legrand and Steunou et al. incorporated Pt nanoparticles (PtNP) together with GOx in the MIL-100(M) $(\mathrm{M}=\mathrm{Fe}, \mathrm{Cr}, \mathrm{Al})$ and MIL-127(Fe) in order to improve the conductivity [47]. The sensor was assembled by successive deposition of MOFs and GOx on the surface of PtNP-CIE (CIE = carbon ink electrode). Among all the MOFs applied, MIL-100(Fe) based biosensor exhibited the best performance, which was 
likely owing to a synergism of the structural properties of MIL-100(Fe) and the catalytic properties of $\mathrm{Fe}^{3+}$. The glucose sensitivity was determined to be $71 \mathrm{~mA} \mathrm{M}^{-1} \mathrm{~cm}^{-2}$ and the response time was under $5 \mathrm{~s}$. The sensors based on other MOFs presented non-linear relationships in the range of low glucose concentration and much longer response times.

Liu et al. reported a composite that was prepared using amino-containing MOF (MIL-101(Al)-NH $\mathrm{NH}_{2}$ ) as the host support to anchor Hemin as an enzyme mimic in order to simulate the peptidic microenvironment in the native peroxidase [48]. The oxidation of 3,3,5,5-tetramethylbenzidine (TMB) by $\mathrm{H}_{2} \mathrm{O}_{2}$ and the oxidation of glucose catalyzed by $\mathrm{GOx}$ were used to evaluate its performance. TMB oxidation demonstrated a linear range with the concentration of $\mathrm{H}_{2} \mathrm{O}_{2}$ from $5.0 \mu \mathrm{M}$ to $200 \mu \mathrm{M}$ $\left(R^{2}=0.994\right)$. For the glucose detection, it was observed to have a linear range from $10 \mu \mathrm{M}$ to $300 \mu \mathrm{M}$ $\left(R^{2}=0.993\right)$.

\section{Conclusions}

In summary, we reviewed a variety of applications of MOF-based immobilized bio-catalysts in chemical conversion, protein digestion, tandem reaction, sensing, and detection. MOFs, as the porous solid supports, normally provide the separation of enzymes (in other words, avoiding aggregation), shielding for enzymes against perturbation conditions, cavity micro-environment that may benefit MOF-enzyme interaction and substrate diffusion, and potential catalytic sites from metal clusters or organic linkers. These benefiting factors, in turn, offer better reusability and better catalytic activity compared to free enzymes. However, it is worth noting that even though this area has been studied for almost a decade, there is still a large gap between benchtop results and practical applications. Many of the catalytic reactions and protein digestion cases are proof-of-concept models at ex vivo conditions. The specific interaction sites between the framework of MOFs and biocatalysts are largely unknown. The same statement can be made for the exact effect of the confined environment in MOF cavities on the diffusion of the substrate and product. The size matching between MOFs' pores and enzymes plays a key role in the encapsulation approach as shown in some examples mentioned. The large enzyme may not be able to enter small MOF pores via post-synthetic method, whereas small enzymes may suffer from leaching problems in large pores. The rational design of MOFs that matches the size of enzymes well and provides excellent substrates/products would be of great interest for future study. In addition, few reported examples have shown the capability to immobilize multiple enzymes in one MOF system for tandem reactions. The development of the multi-enzyme systems would have the potential to gain more commercial popularity owing to their multifunctionalities.

Acknowledgments: This work was supported by the Robert A. Welch foundation through the Welch Endowed Chair to HJZ (A-0030) and the Strategic Transformative Research Program, College of Science, Texas A\&M University.

Author Contributions: This is a review paper. Q.W. and X.L. discussed the scope and the content of the review. Q.W. wrote the manuscript. X.L. and Y.F. edited the manuscript.

Conflicts of Interest: The authors declare no conflict of interest.

\section{Abbreviations}

$\begin{array}{ll}\text { ABTS } & 2,2^{\prime} \text {-Azino-bis(3-ethylbenzothiazoline-6-sulphonic acid) } \\ \text { BPYDC } & 2,2^{\prime} \text {-bipyridine 5,5'-dicarboxylate } \\ \text { BSA } & \text { Bovine serum albumin } \\ \text { CAL-B } & \text { Candida-antarctica-lipase-B } \\ \text { CAT } & \text { Catalase } \\ \text { CIE } & \text { Carbon ink electrode } \\ \text { CYCU } & \text { Chung Yuan Christian University } \\ \text { Cyt c } & \text { Cytochrome c }\end{array}$




$\begin{array}{ll}\text { DMF } & N, N^{\prime} \text {-Dimethylformimade } \\ \text { EDC } & 1 \text {-Ethyl-3-(3-dimethylaminopropyl)carbodiimide } \\ \text { EGFP } & \text { Enhanced green fluorescent protein } \\ \text { ETTC } & 4^{\prime}, 4^{\prime \prime}, 4^{\prime \prime \prime}, 4^{\prime \prime \prime \prime} \text {-(ethene-1,1,2,2-tetrayl)tetrakis-([1,1'-biphenyl]-4-carboxylate) } \\ \text { FITC } & \text { Fluorescein isothiocyanate } \\ \text { GDH } & \text { Glucose dehydrogenase } \\ \text { GOx } & \text { Glucose oxidase } \\ \text { HRP } & \text { Horseradish peroxidase } \\ \text { MCM } & \text { Mobil Composition of Matter } \\ \text { MEE } & \text { Multi-enzyme encapsulation } \\ \text { MG } & \text { Methylene green } \\ \text { MOF } & \text { Metal organic framework } \\ \text { MP-11 } & \text { Microperoxidase-11 } \\ \text { NBD } & 4 \text {-Chloro-7-nitrobenzofurazan } \\ \text { NP } & \text { Nanoparticle } \\ \text { OPAA } & \text { Organophosphorus acid anhydrolase } \\ \text { PCN } & \text { Porous coordination network } \\ \text { PDA } & 1,4 \text {-phenylenediacetic acid } \\ \text { SDC } & \text { 4,4'-stilbenedicarboxylic acid } \\ \text { SEE } & \text { Single-enzyme encapsulation } \\ \text { SOD } & \text { Superoxide dismutase } \\ \text { TATB } & \text { Triazine-1,3,5-tribenzoate } \\ \text { TMB } & \text { Tetramethylbenzidine } \\ \text { ZIF } & \text { Zeolitic imidazolate frameworks }\end{array}$

\section{References}

1. Bornscheuer, U.T.; Huisman, G.W.; Kazlauskas, R.J.; Lutz, S.; Moore, J.C.; Robins, K. Engineering the third wave of biocatalysis. Nature 2012, 485, 185-194. [CrossRef] [PubMed]

2. Cooper, G.M.; Hausman, R.E. The Cell: A Molecular Approach, 3rd ed.; ASM Press: Washington, DC, USA; Sinauer Associates: Sunderland, MA, USA, 2004.

3. Schmid, A.; Dordick, J.S.; Hauer, B.; Kiener, A.; Wubbolts, M.; Witholt, B. Industrial biocatalysis today and tomorrow. Nature 2001, 409, 258-268. [CrossRef] [PubMed]

4. Majewski, M.B.; Howarth, A.J.; Li, P.; Wasielewski, M.R.; Hupp, J.T.; Farha, O.K. Enzyme encapsulation in metal-organic frameworks for applications in catalysis. CrystEngComm 2017, 19, 4082-4091. [CrossRef]

5. Lian, X.; Fang, Y.; Joseph, E.; Wang, Q.; Li, J.; Banerjee, S.; Lollar, C.; Wang, X.; Zhou, H.C. Enzyme-MOF (metal-organic framework) composites. Chem. Soc. Rev. 2017, 46, 3386-3401. [CrossRef] [PubMed]

6. Zhou, Z.; Hartmann, M. Recent progress in biocatalysis with enzymes immobilized on mesoporous hosts. Top. Catal. 2012, 55, 1081-1100. [CrossRef]

7. Zhou, Z.; Hartmann, M. Progress in enzyme immobilization in ordered mesoporous materials and related applications. Chem. Soc. Rev. 2013, 42, 3894-3912. [CrossRef] [PubMed]

8. Xu, C.-P.; Yun, J.W. Influence of aeration on the production and the quality of the exopolysaccharides from Paecilomyces tenuipes C240 in a stirred-tank fermenter. Enzym. Microb. Technol. 2004, 35, 33-39. [CrossRef]

9. Zhou, H.C.; Long, J.R.; Yaghi, O.M. Introduction to metal-organic frameworks. Chem. Rev. 2012, 112, 673-674. [CrossRef] [PubMed]

10. Zhou, H.C.; Kitagawa, S. Metal-organic frameworks (MOFs). Chem. Soc. Rev. 2014, 43, 5415-5418. [CrossRef] [PubMed]

11. Qin, J.S.; Yuan, S.; Wang, Q.; Alsalme, A.; Zhou, H.C. Mixed-linker strategy for the construction of multifunctional metal-organic frameworks. J. Mater. Chem. A 2017, 5, 4280-4291. [CrossRef]

12. Perry Iv, J.J.; Perman, J.A.; Zaworotko, M.J. Design and synthesis of metal-organic frameworks using metal-organic polyhedra as supermolecular building blocks. Chem. Soc. Rev. 2009, 38, 1400-1417. [CrossRef] [PubMed] 
13. Tranchemontagne, D.J.; Mendoza-Cortes, J.L.; O'Keeffe, M.; Yaghi, O.M. Secondary building units, nets and bonding in the chemistry of metal-organic frameworks. Chem. Soc. Rev. 2009, 38, 1257-1283. [CrossRef] [PubMed]

14. Lee, J.Y.; Farha, O.K.; Roberts, J.; Scheidt, K.A.; Nguyen, S.T.; Hupp, J.T. Metal-organic framework materials as catalysts. Chem. Soc. Rev. 2009, 38, 1450-1459. [CrossRef] [PubMed]

15. Long, J.R.; Yaghi, O.M. The pervasive chemistry of metal-organic frameworks. Chem. Soc. Rev. 2009, 38, 1213-1214. [CrossRef] [PubMed]

16. Cozzolino, A.F.; Brozek, C.K.; Palmer, R.D.; Yano, J.; Li, M.; Dincă, M. Ligand redox non-innocence in the stoichiometric oxidation of $\mathrm{Mn}_{2}$ (2,5-dioxidoterephthalate) (Mn-MOF-74). J. Am. Chem. Soc. 2014, 136, 3334-3337. [CrossRef] [PubMed]

17. Hirai, K.; Reboul, J.; Morone, N.; Heuser, J.E.; Furukawa, S.; Kitagawa, S. Diffusion-coupled molecular assembly: Structuring of coordination polymers across multiple length scales. J. Am. Chem. Soc. 2014, 136, 14966-14973. [CrossRef] [PubMed]

18. Sumida, K.; Rogow, D.L.; Mason, J.A.; McDonald, T.M.; Bloch, E.D.; Herm, Z.R.; Bae, T.-H.; Long, J.R. Carbon dioxide capture in metal-organic frameworks. Chem. Rev. 2012, 112, 724-781. [CrossRef] [PubMed]

19. Murray, L.J.; Dinca, M.; Long, J.R. Hydrogen storage in metal-organic frameworks. Chem. Soc. Rev. 2009, 38, 1294-1314. [CrossRef] [PubMed]

20. Yanai, N.; Kitayama, K.; Hijikata, Y.; Sato, H.; Matsuda, R.; Kubota, Y.; Takata, M.; Mizuno, M.; Uemura, T.; Kitagawa, S. Gas detection by structural variations of fluorescent guest molecules in a flexible porous coordination polymer. Nat. Mater. 2011, 10, 787-793. [CrossRef] [PubMed]

21. Rosi, N.L.; Eckert, J.; Eddaoudi, M.; Vodak, D.T.; Kim, J.; O’Keeffe, M.; Yaghi, O.M. Hydrogen storage in microporous metal-organic frameworks. Science 2003, 300, 1127-1129. [CrossRef] [PubMed]

22. Zhao, X.; Xiao, B.; Fletcher, A.J.; Thomas, K.M.; Bradshaw, D.; Rosseinsky, M.J. Hysteretic adsorption and desorption of hydrogen by nanoporous metal-organic frameworks. Science 2004, 306, 1012-1015. [CrossRef] [PubMed]

23. Horcajada, P.; Gref, R.; Baati, T.; Allan, P.K.; Maurin, G.; Couvreur, P.; Férey, G.; Morris, R.E.; Serre, C. Metal-organic frameworks in biomedicine. Chem. Rev. 2012, 112, 1232-1268. [CrossRef] [PubMed]

24. Zhang, T.; Lin, W. Metal-organic frameworks for artificial photosynthesis and photocatalysis. Chem. Soc. Rev. 2014, 43, 5982-5993. [CrossRef] [PubMed]

25. Bosch, M.; Sun, X.; Yuan, S.; Chen, Y.P.; Wang, Q.; Wang, X.; Zhou, H.C. Modulated synthesis of metal-organic frameworks through tuning of the initial oxidation state of the metal. Eur. J. Inorg. Chem. 2016, 2016, 4368-4372. [CrossRef]

26. Wang, X.; Makal, T.A.; Zhou, H.-C. Protein immobilization in metal-organic frameworks by covalent binding. Aust. J. Chem. 2014, 67, 1629-1631. [CrossRef]

27. Raja, D.S.; Liu, W.-L.; Huang, H.-Y.; Lin, C.-H. Immobilization of protein on nanoporous metal-organic framework materials. Comments Inorg. Chem. 2015, 35, 331-349. [CrossRef]

28. Mehta, J.; Bhardwaj, N.; Bhardwaj, S.K.; Kim, K.-H.; Deep, A. Recent advances in enzyme immobilization techniques: Metal-organic frameworks as novel substrates. Coord. Chem. Rev. 2016, 322, 30-40. [CrossRef]

29. Chen, Y.; Ma, S. Biomimetic catalysis of metal-organic frameworks. Dalton Trans. 2016, 45, 9744-9753. [CrossRef] [PubMed]

30. Gkaniatsou, E.; Sicard, C.; Ricoux, R.; Mahy, J.-P.; Steunou, N.; Serre, C. Metal-organic frameworks: A novel host platform for enzymatic catalysis and detection. Mater. Horiz. 2017, 4, 55-63. [CrossRef]

31. Jung, S.; Kim, Y.; Kim, S.J.; Kwon, T.H.; Huh, S.; Park, S. Bio-functionalization of metal-organic frameworks by covalent protein conjugation. Chem. Commun. 2011, 47, 2904-2906. [CrossRef] [PubMed]

32. Lykourinou, V.; Chen, Y.; Wang, X.-S.; Meng, L.; Hoang, T.; Ming, L.-J.; Musselman, R.L.; Ma, S. Immobilization of mp-11 into a mesoporous metal-organic framework, mp-11@mesomof: A new platform for enzymatic catalysis. J. Am. Chem. Soc. 2011, 133, 10382-10385. [CrossRef] [PubMed]

33. Hartmann, M. Ordered mesoporous materials for bioadsorption and biocatalysis. Chem. Mater. 2005, 17, 4577. [CrossRef]

34. Feng, D.; Liu, T.-F.; Su, J.; Bosch, M.; Wei, Z.; Wan, W.; Yuan, D.; Chen, Y.-P.; Wang, X.; Wang, K.; et al. Stable metal-organic frameworks containing single-molecule traps for enzyme encapsulation. Nat. Commun. 2015, 6, 5979. [CrossRef] [PubMed] 
35. Liang, K.; Ricco, R.; Doherty, C.M.; Styles, M.J.; Bell, S.; Kirby, N.; Mudie, S.; Haylock, D.; Hill, A.J.; Doonan, C.J.; et al. Biomimetic mineralization of metal-organic frameworks as protective coatings for biomacromolecules. Nat. Commun. 2015, 6, 7240. [CrossRef] [PubMed]

36. Casadonte, F.; Pasqua, L.; Savino, R.; Terracciano, R. Smart trypsin adsorption into N-(2-aminoethyl)-3aminopropyl-modified Mesoporous Silica for Ultra Fast protein digestion. Chem. Eur. J. 2010, 16, 8998-9001. [CrossRef] [PubMed]

37. Liu, W.-L.; Lo, S.-H.; Singco, B.; Yang, C.-C.; Huang, H.-Y.; Lin, C.-H. Novel trypsin-FITC@MOF bioreactor efficiently catalyzes protein digestion. J. Mater. Chem. B 2013, 1, 928-932. [CrossRef]

38. Liu, W.-L.; Wu, C.-Y.; Chen, C.-Y.; Singco, B.; Lin, C.-H.; Huang, H.-Y. Fast multipoint immobilized MOF bioreactor. Chem. Eur. J. 2014, 20, 8923-8928. [CrossRef] [PubMed]

39. Shih, Y.-H.; Lo, S.-H.; Yang, N.-S.; Singco, B.; Cheng, Y.-J.; Wu, C.-Y.; Chang, I.H.; Huang, H.-Y.; Lin, C.-H. Trypsin-immobilized metal-organic framework as a biocatalyst in proteomics analysis. ChemPlusChem 2012, 77, 982-986. [CrossRef]

40. Li, P.; Moon, S.-Y.; Guelta, M.A.; Harvey, S.P.; Hupp, J.T.; Farha, O.K. Encapsulation of a nerve agent detoxifying enzyme by a mesoporous zirconium metal-organic framework engenders thermal and long-term stability. J. Am. Chem. Soc. 2016, 138, 8052-8055. [CrossRef] [PubMed]

41. Lian, X.; Chen, Y.-P.; Liu, T.-F.; Zhou, H.-C. Coupling two enzymes into a tandem nanoreactor utilizing a hierarchically structured MOF. Chem. Sci. 2016, 7, 6969-6973. [CrossRef] [PubMed]

42. Tietze, L.F.; Beifuss, U. Sequential transformations in organic chemistry: A synthetic strategy with a future. Angew. Chem. Int. Ed. Engl. 1993, 32, 131-163. [CrossRef]

43. Lian, X.; Erazo-Oliveras, A.; Pellois, J.-P.; Zhou, H.-C. High efficiency and long-term intracellular activity of an enzymatic nanofactory based on metal-organic frameworks. Nat. Commun. 2017, 8, 2075. [CrossRef] [PubMed]

44. Wang, J. Electrochemical glucose biosensors. Chem. Rev. 2008, 108, 814-825. [CrossRef] [PubMed]

45. Yoo, E.-H.; Lee, S.-Y. Glucose biosensors: An overview of use in clinical practice. Sensors (Basel) 2010, 10, 4558. [CrossRef] [PubMed]

46. Ma, W.; Jiang, Q.; Yu, P.; Yang, L.; Mao, L. Zeolitic imidazolate framework-based electrochemical biosensor for in vivo electrochemical measurements. Anal. Chem. 2013, 85, 7550-7557. [CrossRef] [PubMed]

47. Patra, S.; Hidalgo Crespo, T.; Permyakova, A.; Sicard, C.; Serre, C.; Chausse, A.; Steunou, N.; Legrand, L. Design of metal organic framework-enzyme based bioelectrodes as a novel and highly sensitive biosensing platform. J. Mater. Chem. B 2015, 3, 8983-8992. [CrossRef]

48. Qin, F.-X.; Jia, S.-Y.; Wang, F.-F.; Wu, S.-H.; Song, J.; Liu, Y. Hemin@metal-organic framework with peroxidase-like activity and its application to glucose detection. Catal. Sci. Technol. 2013, 3, 2761-2768. [CrossRef]

(C) 2018 by the authors. Licensee MDPI, Basel, Switzerland. This article is an open access article distributed under the terms and conditions of the Creative Commons Attribution (CC BY) license (http://creativecommons.org/licenses/by/4.0/). 